\title{
Binary Opposition, Chronology of Time and Female Identity in William Faulkner's A Rose for Emily
}

\author{
Forough Barani (corresponding author) \\ Department of English, Faculty of Modern Languages \& Communication, Universiti Putra Malaysia, 43400 UPM Serdang, Selangor, MALAYSIA \\ E-mail address: Forough.barani@yahoo.com \\ Wan Roselezam Wan Yahya \\ Department of English, Faculty of Modern Languages \& Communication, Universiti Putra Malaysia, 43400 UPM Serdang, Selangor, MALAYSIA \\ E-mail address: rose@fbmk.upm.edu.my
}

Received: 03-11-2013

doi:10.7575/aiac.ijalel.v.3n.2p.155
Accepted: 13-12-2013

Published: 01-03-2014

This study was a part of a Research Project: Bakhtinian, feminist, and post colonial reading of fictional and nonfictional works by Malaysian, British, African and Canadian writers (Code: 06-05-10-11021RU) 2010-2012. University Putra Malaysia.

\begin{abstract}
In any work of imaginative literature, binary oppositions, the specifics of time and the characterization of the protagonist play some role, no matter how small and insignificant. Reading Faulkner's short story "A Rose for Emily" in light of the conflicts of the old and the new, the tradition and the traditionless, the chronology of time and its effect on the reader, and the characterization of the female protagonist was indicative of the influence of cultural elements in analyzing the story. While Faulkner was doubtless a major artist in terms of depicting the life of Southerners of the time and changes in the norms and codes of their lifestyle, the reader and the cautious critic also will have a distinct, and often contradictory, interpretation of a given text from the point of view and theoretical perspective that he/she adopts.
\end{abstract}

Keywords: opposites, chronology, time, tradition, decay

\section{Introduction}

William Faulkner's fascinating and rich short story A Rose for Emily is open to many kinds of reading and analysis. As a way of approaching the cultural heritage of the text, examining binary oppositions and the conflicts between southerner and northerner, old and new, traditional and traditionless, and gentility and middle-lower class are of primary concern in this paper. This structuralist reading of the text is a feasible approach to analyzing culture since it provides a proper ground for the development of a cultural discussion of the context of this short story, in which Faulkner raises the issue of changing a southerner's values in a very dramatic turn. Faulkner, born and raised in Mississippi, was accustomed to the changing south. Being born at the turn of the twentieth century, he was able to see how the south was changing. Most of his stories dwell on characterization of the usual southern characters, so there is no doubt that his heritage played a part in his stories.

In addition, the handling of "time", with all its complexities, is a real issue when reading A Rose for Emily. As readers follow the narrative they will find themselves entangled at some point in the presence of the narrator and many flashbacks to different times in the past. Although the anonymous narrator keeps the reader in a state of mystery and illusion, there are many clues and much evidence that leads the reader to the horror of the last scene. A close reading of the text indicates that there are different "pasts" and that their events are narrated via many flashbacks, but without any chronological order. We will describe the major pasts chronologically as: past (i), past (ii) and past (iii).

On the basis of reading the chronology of $A$ Rose for Emily and underlining the significance of the binary oppositions, this study also gets help from a feminist perspective so as to shed light on cultural issues and the representation of the female character in the text. In this light, the position of the female in the context of the society of the time is related. Further analysis addresses the issue of traditional and new values with respect to the female's position. By doing so, this study aims to fulfil its goal of examining the influence of culture in Faulkner's A Rose for Emily from two structuralist and feminist approaches.

\section{Confrontation of Opposites: Traditional and Traditionless, Old and New}

Part I of the story comprises three phases in different times; it begins with Miss Emily's funeral and then, in the second paragraph, it moves back in time to the past (i) when Miss Emily's house is described, and then to the past (iii) where a new generation examines the new status of this once luxurious house. Previously, the house was a "big, squarish frame house that had once been white, decorated with cupolas and spires and scrolled balconies in the heavily lightsome style of the seventies, set on what had once been our most select street" (119). This scene provides a very typical description 
of houses at the time of narration. Afterwards, "garages and cotton gins had encroached and obliterated even the august names of that neighborhood; only Miss Emily's house was left, lifting its stubborn and coquettish decay above the cotton wagons and the gasoline pumps - an eyesore among eyesores" (119). At the end of this passage, the idea of decay and rottenness is completed by a final image of a cemetery where Miss Emily is going to join the history of Jefferson, "And now Miss Emily had gone to join the representatives of those august names where they lay in the cedarbemused cemetery among the ranked and anonymous graves of Union and Confederate soldiers who fell at the battle of Jefferson" (119).

From this beginning through to the end, the narrator emphasizes the opposing features of decay and freshness and, in another sense, old and new - both referring to objects and persons, ages and ideas. "Alive, Miss Emily had been a tradition, a duty, and a care; a sort of hereditary obligation upon the town" (119), when "Colonel Sartoris, the mayor, invented an involved tale to the effect that Miss Emily's father had loaned money to the town" (119-120), so remitting her taxes. Later, the next generation "with its more modern ideas," comes and shows "some little dissatisfaction" with this arrangement; so they sent Miss Emily "a tax notice". And this time is in past (iii) when the new generation "received in reply a note on paper of an archaic shape, in a thin, flowing calligraphy in faded ink" (120). The archaic and old elements ascribed to Miss Emily are clear, as in the description of her house visited by this new generation. New values and ideas stand in front of old ones,

a dim hall from which a stairway mounted into still more shadow. It smelled of dust and disuse, a close, dank smell. The Negro led them into the parlor. It was furnished in heavy, leather-covered furniture. When the Negro opened the blinds of one window, they could see that the leather was cracked. (120)

Images of dimness, shadows, dust and dank smells, the cracked leather and nearly everything associated with her connote decay and oldness. Even the sun shines with only a single ray in this dark gloomy house of shadows. Again the narrator ends the description of the setting with the "crayon portrait of Miss Emily's father" (120), who is dead, to complete his picture of decay.

"A small, fat woman in black" (121), Miss Emily appears to this group of visitors. It is interesting that while the matter of "time" is very significant in the story, after describing her in black, the second thing concerning Emily's appearance is her "thin gold chain descending to her waist and vanishing into her belt" (121), as if she is preceding the "Golden Time" by hiding or ignoring it.

Meanwhile, incidents in past time (ii) are narrated in the second, third and fourth parts of the story, when the whole story of Homer Barren is presented in a haphazard and non-chronological order, shifting back and forth in time: first the spreading of the smell (past $\mathrm{ii}_{\mathrm{d}}$ ), then the appearance of Homer Barren and his dates with Miss Emily and the beginning of the gossip (past $\mathrm{ii}_{\mathrm{a}}$ ), the arsenic-buying scene (past $\mathrm{ii}_{\mathrm{b}}$ ), and finally (past $\mathrm{ii}_{\mathrm{c}}$ ), in part IV, Homer's reappearance and then his final disappearance. (Note: the chronological order of events, from furthest past to nearest past, is $\mathrm{ii}_{\mathrm{a}}, \mathrm{ii}_{\mathrm{b}}, \mathrm{ii}_{\mathrm{c}}, \mathrm{ii}_{\mathrm{d}}$.)

The narrator identifies a time in the second part of the story: "That was two years after her father's death and a short time after her sweetheart, the one we believed would marry her, had deserted her" (122). And then s/he goes on to relate how, little by little, Miss Emily's isolation deepened, "[a]fter her father's death she went out very little; after her sweetheart went away, people hardly saw her at all" (122). And at another time there is a confrontation between death and life; she is mentally dead since she has no will to communicate, while she is physically alive with the indication of the "market basket", "the only sign of life about the place was the Negro man, a young man then, going in and out with a market basket" (122). And this is the time when the smell develops (past $\mathrm{ii}_{\mathrm{d}}$ ). Note how the narrator ironically indicates the contrasting qualities of the two castes, "the gross, teeming world" and "the high and mighty" (122). If Griersons are of a higher social rank, then how can the smell spreading from Miss Emily's house be justifiable? The respect that the older generation holds for Emily and the impatient behaviour of the younger generation is also made plain in their conversation about the smell: "Send her word to have her place cleaned up. Give her a certain time to do it in, and if she don't..." (122), and "Dammit, sir," Judge Stevens said, "will you accuse a lady to her face of smelling bad?" (122)

Finally, for the second time, "three graybeards and one younger man, a member of the rising generation" (122) set out on their journey to her castle. Miss Emily is presented in darkness and "her upright torso motionless as that of an idol" (123), again an image of death is offered.

In the next scene, when people begin to feel sorry for her, remembering old lady Wyatt, her great aunt who "had gone completely crazy at last" (123), the comparison between gentility and the middle-lower class intensifies. "[The] Griersons held themselves a little too high for what they really were", and in her youth "None of the young men were quite good enough for Miss Emily" (123). Another contrast which is somewhat mixed up with these class divisions is the image that "we" - the younger generation of the middle class, the narrator - once had of Miss Emily, in our thoughts as a "tableau, a slender figure in white" (123), but in the actual present an image of her in black with suspicions about her sanity.

The narrator relates the relationship between Homer Barron, a northerner, and Miss Emily, a southerner, and in this way presents a very indicative set of oppositions. The proud, indomitable autocracy of the south, Emily's father, and those other "older people" who said that "even grief could not cause a real lady to forget noblesse oblige" (124) are in contrast to Homer Barron, "a Yankee, a big, dark, ready man, with a big voice and eyes lighter than his face" (124) with his ungentle manners, "Whenever you heard a lot of laughing anywhere about the square, Homer Barron would be in the center of the group" (124). 
Thus it was that the whispering began, "Poor Emily, Do you suppose it's really so?" they said to one another. "Of course it is. What else could..." (125). While she continued dating Homer "[s]he carried her head high enough - even when we [the narrator] believed that she was fallen" (125). It was over a year after they had begun to say "poor Emily" when she bought poison. And the past ( $\mathrm{ii}_{\mathrm{b}}$ ) occurs with that self-revealing dialogue between Miss Emily and the druggist, "Miss Emily just stared at him, her head tilted back in order to look him eye for eye, until he looked away and went and got the arsenic and wrapped it up" (126).

As the nature of her dialogue indicates, she repeats her sentences several times in an odd and unusual manner without any further clarification: "I want some poison. I want the best you have" (125). And also, in the first dialogue, "See Colonel Sartoris. I have no taxes in Jefferson" (121). It is quite clear that she does not differentiate between the dead and the living, another determining and opposing element in the story, as it is already ten years since Colonel Sartoris died. Also, before this incident but after her father's death, when the ladies went to her house to offer their sympathies and help, she received them at the door, "dressed as usual and with no trace of grief on her face. She told them that her father was not dead. She did that for three days" (123), and much later her love for the dead body of Homer is quite revealing in that she had no understanding of time and decay.

Faulkner, particularly in the opposition of south and north, attempts to draw attention to the changing south. But it seems that Faulkner aims to honour the old southern traditions, rather than allowing them to fade away over time. One way in which Faulkner envisions the south is by using symbolism, in the death of Homer Barron, to show that the ideals of the north should not replace those of the south. Thomas Dilworth argues that, "Emily briefly rebelled against southern values and then, by ending her affair with him [Homer Barron] [...] she conformed again to those [southern] values" (251). It appears that Miss Emily was by no means ready to give up her lover, Homer Barron, until a twoweek visit from her female cousins who "probably opposed her consorting with a socially inferior Northerner" (Dilworth 255). In fact, Miss Emily is "denying progress" (Scherting 405) in order to stop the changing traditions of the south.

Petry argues that, of the five adjectives used to describe Miss Emily, "dear, inescapable, impervious, tranquil, and perverse", when part four ends, only four of the five adjectives actually describe her. The last adjective, "perverse", does not describe Miss Emily until the very end of the story, in Part 5. This foreshadowing could be Faulkner's way of alluding to the fact that southern ideals are becoming perverse and perverted. These, the ideals held highly by southerners, were beginning to crumble and to be "directed away from what is right or good" (i.e. "perverse"). Moreover, what had once been "dear, inescapable, impervious, [and] tranquil" (128) in the south was now, in Faulkner's mind, being directed in a new way - no longer right or good - that is perverse.

Conceivably, the best exemplification of how Faulkner's view of the south influences his writing is when the narrator speaks of Miss Emily at the beginning of Part 5. The old Confederate wanted men to come to honour Miss Emily, possibly an example of the fact that Faulkner views the south as no longer a place that has little variable change, but rather one that has nearly been phased out. Even those who still believed in a "Southern lifestyle" were "confusing time with its mathematical progression". West declares, "Emily is a 'monument' of Southern gentility [...] an ideal of past values". Faulkner knew there was change sweeping through the south and that, like the long life of Miss Emily, it would soon die away, just as she had.

The new generation's perspective and set of values are depicted in the fourth part of the story, which stands against the old values. "We" thought "She will kill herself", the narrator begins in the fourth part. So, in this part of only ten short paragraphs, the "we" and their ideas, that represent the new generation, are repeated more than twenty times, intentionally and deliberately, by Faulkner. In the following paragraph the repetition of the pronoun "we" is noteworthy,

Daily, monthly, yearly [we] watched the Negro grow grayer and more stooped, going in and out with the market basket. Each December [we] sent her a tax notice, which would be returned by the post office a week later, unclaimed. Now and then [we] would see her in one of the downstairs windows - she had evidently shut up the top floor of the house - like the carven torso of an idol in a niche, looking or not looking at us, [we] could never tell which. Thus she passed from generation to generation - dear, inescapable, impervious, tranquil, and perverse. (Italics added) (128)

Indeed this was how "she passed from generation to generation"; the elders of the town "who said that even grief could not cause a real lady to forget noblesse oblige"(124); the same generation as Emily herself, "all the young men her father had driven away", "the very old men, some in their brushed Confederate uniforms, on the porch and the lawn, talking of Miss Emily as if she had been a contemporary of theirs, believing that they had danced with her and courted her perhaps" (129); the new generation, the officers and ladies gossiping; the new younger generation, the "we" narrator; the newest generation, "the daughters and granddaughters of Colonel Sartoris' contemporaries" to whom she gave lessons in china-painting; and finally the children of the granddaughters of Colonel Sartoris, "the painting pupils grew up and fell away and did not send their children to her ... . (128)

And, meanwhile, her hair was turning grey, "During the next few years it grew grayer and grayer until it attained an even pepper-and-salt iron-gray" (127). It was after her painting classes that the front door was closed, after the last one left, and "remained closed for good" (128). Afterwards, when "the newer generation became the backbone and the spirit of the town" and the town got free postal delivery, it was only Miss Emily who refused to attach a mailbox to her door; though she was not expecting any letters or parcels, she opposed the new developments as well. Nebeker, in his thematic implications on the point of view in "A Rose for Emily", declares, 
With the passage of years, only Emily, symbolic of the indomitable but dying Old South in all its decadence, pride, refusal to admit the changing order, remains distinguishable, definable. We [the narrator] have admitted the change, accepted it, merged into it, become a part of them. Only Emily "passed from generation to generation-dear [to the old order], inescapable [to her contemporary protectors], impervious [to the new order], tranquil [in her madness], and perverse [turned to the illusory past instead of reality]. (8-9)

"And so she died. Fell ill in the house filled with dust and shadows ... her gray head propped on a pillow yellow and moldy with age and lack of sunlight" (129). The narrative moves forward, in time, to the beginning of the story, Miss Emily's funeral. And it is in the last part of the story that Faulkner makes his final and revealing comment on the "confusing time with its mathematical progression", in which "to whom [the old] all the past is not a diminishing road but, instead, a huge meadow which no winter ever quite touches, divided from them now by the narrow bottle-neck of the most recent decade of years" (129). The last scene of the story contains the most appalling binary oppositions, between, on the one hand, the bridal and the bed - that is, in a sense, a new birth - and, on the other, death and the tomb. After a very detailed description of the once prepared wedding room with its now pale rose-coloured picture, "upon the valance curtains of faded rose color, upon the rose-shaded lights", and the current status of the dusty, deathstricken, tomb-like room, the reader receives the final shock in a short accurate sentence, "The man himself lay in the bed" (130), "What was left of him", after nearly forty years "lain in the attitude of an embrace" (130). The narrator ends his/her narration with a final indication that perhaps Miss Emily slept with the dead body of her beloved, "Then we noticed that in the second pillow was the indentation of a head. One of us lifted something from it, and leaning forward, that faint and invisible dust dry and acrid in the nostrils, we saw a long strand of iron-gray hair" (130).

The symbolic representation of the colour rose - even in the title of the story - may also be a part of Faulkner's vision of a changing south that should not change. Laura Getty makes a good argument for this,

[a] [the] combination of the rose-colored bedroom and Homer as a dried rose could serve as a relic of the past. Homer's body could be like a rose pressed between the pages of a book, kept tucked away in a seldom used, rose colored room which at times can be opened. (230)

As roses die, only a memory of them is preserved. Perhaps, in the same way, Faulkner was using the rose as a symbol to represent how southern ideals were eroding away, leaving only memories of old traditions and ideas as rare afterthoughts. Moreover, during the 1800 s, the south used roses as tokens of love, or at least deep friendship. It is possible then that the symbolic meaning of the rose could have two different, i.e. dual, meanings. Faulkner may be using the rose as a symbol of how the love and deep respect for the old south were replacing those of a new, more permissive south.

\section{Female Entrapped: Miss Emily in the Attic}

The feminist movement has attempted to elevate the status of women to a level equal with men. Feminists have fought for the right of women to be free from the old social restraints which have been in place for so long. A feminist believes a woman should be strong and independent. In some ways the main character, Emily, is this kind of woman, but for the most part she is portrayed as weak and fragile. Throughout the story, Emily is depicted as a weak and dependent woman, as shown in the way she is treated by the townsfolk. When her father died and she had no man to care for her, the town absolved her of any tax liability. The people of the town attempted to accommodate her needs by offering their help and sympathy. The townspeople also tried to be considerate of her eccentricities. They extended her courtesy because she was a lady with no one, save for her servant. This taking care of Emily by the town shows the opinion of women at that time. Without a man, Emily was considered somewhat helpless. Everyone felt as if they needed to help her.

At the beginning of the third part, the narrator informs us how Miss Emily, with "her hair cut short", makes herself look like a girl and how the image of an angel emerges after that, with its connotations of innocence and purity but, in a "sort of tragic and serene" way, it foreshadows a tragic end. Another way in which Emily represents females as dependent and childlike is her reluctance to admit her father's death. When he dies, she refuses to let anyone remove his body from their house. It is as if she feels she needs his comforting and protection. Without a man, she is lost. At the end of the story this situation arises again. The man who Emily had a relationship with is found dead and decayed in an upstairs bedroom after her death. There is evidence that she would lay in the bed with the man after his death. This is another way in which Emily is portrayed as needy and weak. She feels she needs a man so badly that she must keep her lover, even after his death. I think most feminists would read this interpretation into "A Rose for Emily".

Perhaps the only way Emily was portrayed as strong or independent is in her lifestyle. She lives alone with only a servant to give her any assistance. She does what she wants without concern for the people around her. In this way, she shows some evidence of the qualities of independence and self-reliance that feminists believe women should exhibit. Faulkner's strange and almost disturbing story addresses certain social issues, mainly the role and demeanour of women during the early twentieth century. It is a social commentary in the guise of a short story.

Judith Fetterley also believed that Emily shows her strong personality in her lifestyle. She lays the blame not on Emily's character but on the patriarchal system of the old south, which punishes a woman for being independent, assertive and generally unladylike. In this kind of reading of the text, Emily's dominant personality will naturally clash with the collective interests of the community of Jefferson. It is worth noticing that all the people - with the exception of the two cousins and some women consoling her after her father's death - with whom Emily has some contact are male, and it 
seems that she has a sort of power over them such that most of them are reluctant to encounter her further: In the arsenic-buying scene, when the druggist is insisting to know her reasons for buying the poison,

Miss Emily just stared at him, her head tilted back in order to look him eye for eye, until he looked away and went and got the arsenic and wrapped it up. The Negro delivery boy brought her the package; the druggist didn't come back. (126)

And also in the case of Emily dating Homer, when the ladies considered it a "disgrace to the town and a bad example to the young people":

The men did not want to interfere, but at last the ladies forced the Baptist minister - Miss Emily's people were Episcopal - to call upon her. He would never divulge what happened during that interview, but he refused to go back again. (126)

Elements of mystery and the grotesque that exist in the story, and the isolation of the "self" because of the inability to establish human communication, remind the reader of "the mad woman in the attic". Yet, just like what Gilbert and Gubar described in their discussion of Bertha, a mad woman, in Jane Eyre, Miss Emily is not a self-imprisoned woman but, as was stated earlier, one entrapped by the codes and norms of society. While she is not willing to communicate and just stays inside, behind the closed door of her house, this might be suggestive of her inner shadowy consciousness, and of the outside, the real world of the everyday life; "but the front door remained closed" (127), for almost six months she did not appear on the streets.

Her image, at the window and behind the door, has been described many times as a motionless idol with no sign of life, as if she has imprisoned herself inside the house, and the window and the door are the only way out to the actual world, "a window that had been dark was lighted and Miss Emily sat in it, the light behind her, and her upright torso motionless as that of an idol" (123). Later on, the window motif becomes more evident when, "[n]ow and then we would see her in one of the downstairs windows - she had evidently shut up the top floor of the house - like the carven torso of an idol in a niche, looking or not looking at us, we could never tell which" (128).

Yet the old traditional set of values and the elders of the town, in contrast to the new generations, mostly during the Civil War period, had a deep respect for women and their dignity. So it is in the changing southern society of her late age that Emily turns to being more isolated and detached from others. The women of the town "began to say that [Miss Emily's relationship with Homer Barron] was a disgrace to the town", while the men strayed away from confronting Miss Emily. The women of the town "forced the Baptist minister [...] to call upon her" (126), to enquire about her relations with Homer Barron. Even then, a forced confrontation never occurs between the minister and Miss Emily again.

Even when they smell Homer's decaying body in Miss Emily's home, the men do not wish to confront Miss Emily on the matter of the smell, although neighbours complained of the stench issuing from her house, because no one should "accuse a lady to her face of smelling bad" (122). Instead of confronting Miss Emily on the matter, they sneaked around the house to sprinkle lime, to limit the smell of dead things in the yard. In keeping with the traditions that many in the south held, that men should respect women, Faulkner's representation of the south is made clear.

Men in the south were expected to treat women with respect, "women of class were not to be troubled by certain worldly obligations" (Dilworth 254). It can be interpreted that Faulkner believed that men in the south should take care of women. Faulkner states, "Miss Emily had been a tradition, a duty, and a care" (119) of the town. When new town officials took office, they demanded that Miss Emily pay taxes, which she never had to do before. However, "only a woman could have believed" the story concocted by the old town leaders. As Dilworth believes, this is reason enough to support the stance that women are not to be "troubled by certain worldly obligations" (254).

\section{Conclusion}

The restructuring of the south during the twentieth century changed it in many ways. Some would say for the better, some for the worse, but whichever way it is looked at - the south was changed. The way Faulkner writes "A Rose for Emily", with his knowledge of and involvement with the South throughout his life - showing deep symbolic elements of Southern culture in the story - reveals that Faulkner possibly believes that, as they die, others will look back on the day, just as the Confederate soldiers did, when Miss Emily died. Jack Scherting puts it so well: "unable to confront the realities of life in post bellum America, that element of Southern society continued to cherish the corpse of a beloved but decayed ideal" (405).

Along the same lines, a feminist reading of the text agrees with the structural study of the binary oppositions apparent in the text, in the different set of values that emerged in the next generation of southerners - which in its own way contributes to the isolation of Miss Emily. A picture is painted - Miss Emily's death is like marking the death of the ideals of generations that embraced those ideals before her.

Reading "A Rose for Emily" in light of the aforementioned critical perspectives was indicative of the influence of cultural elements on analyzing the story. While Faulkner was in no doubt a major artist, adept at depicting the lives of southerners of the time, and changes in the norms and codes of their lifestyle, the reader and cautious critic will also have a distinct, and often contradictory, interpretation of a given text from the point of view and theoretical perspective that he/she adopts. 


\section{References}

Dilworth, T. (1999). A Romance to Kill for: Homicidal Complicity in Faulkner's "A Rose for Emily. Studies in Short Fiction 36(3), 251-62.

Faulkner, W. (1943). A Rose for Emily. Collected Stories of William Faulkner. New York: Random House, 119130. Print.

Fetterley, J. (1978). The Resisting Reader: A Feminist Approach to American Literature." Bloomington: Indiana UP, 34-35.

Getty, Laura J. (2005). Faulkner's A Rose for Emily. Explicator, 63(4), 230-34.

Nebeker, H.E. (1970). Emily's Rose of Love: Thematic Implications of Point of View in Faulkner's "A Rose for Emily"." The Bulletin of the Rocky Mountain Modern Language Association, 24(1), 3-13. Print.

Nebeker, H.E. (1970). Emily's Rose of Love: A Postscript." The Bulletin of the Rocky Mountain Modern Language Association, 24(4), 190-91.

Petry, A.H. (1986). Faulkner's 'A Rose for Emily."' Explicator 44, 52-54.

Scherting, J. (1980). Emily Grierson's Oedipus Complex: Motif, Motive, And Meaning in Faulkner's 'A Rose for Emily'." Studies in Short Fiction 17(4)397-405.

Watkins, F.C. (1954). The Structure of "A Rose for Emily"." Modern Language Notes, 69(7), 508-10. Print.

West, Ray B. Jr. (1988). Faulkner's A Rose for Emily." Short Story Criticism, 1, 148-50. 